\title{
PENGARUH EXPERIENTIAL MARKETING TERHADAP NIAT MENGUNJUNGI KEMBALI DI RUMAH MAKAN DENGAN KEPUASAN KONSUMEN SEBAGAI VARIABEL MEDIASI
}

\author{
Nourissa Dinda Syachadi \\ Universitas Negeri Surabaya \\ dindasyachadi011@gmail.com \\ Widyastuti \\ Universitas Negeri Surabaya \\ widyastuti@unesa.ac.id
}

\begin{abstract}
This research aims to determine the effect of experiential marketing on the revisit intention at Si Bolang restaurant and customer satisfaction as mediation variables. The population is the customer of Si Bolang restaurant, with a total of respondents 200. The study method is quantitative and data collection using Google Forms online questionnaire. Data analysis used is Path analysis with SPSS version 25 program, and the variables used included experiential marketing, customer satisfaction, and revisit intention. Data analysis conducted are validity, reliability, path analysis, and Sobel. This research shows a significant effect of experiential marketing on revisit intention; subsequently, customer satisfaction has a significant effect on the revisit intention. Next, experiential marketing has a significant effect on revisit intention, and this study concludes that it is proven that customer satisfaction has a role as a mediation variable between experiential marketing and revisit intention. This research is based on current conditions making eating necessary to meet hunger and turning into culinary tourism with lifestyle changes, making the restaurant industry marketing activities focus on atmosphere, design, hospitality, and other intangible factors. It is necessary to pay attention to strategies in providing experiences to consumers, such as improving the taste of food, developing menus, increasing food presentation, increasing restaurant concepts and improving service in order to increase comfort in dining such as eating at home, so that grow a sense of satisfaction and provide encouragement to consumers' intentions to make repeat visits.
\end{abstract}

Keywords: culinary; customer satisfaction; experiential marketing; restaurant; revisit intention.

\section{PENDAHULUAN}

Bisnis kuliner di Indonesia semakin berkembang. Meningkatnya bisnis kuliner ini dipicu oleh kebutuhan masyarakat yang didukung dengan adanya pola hidup masyarakat yang mendorong pekerja lebih sering makan di luar daripada makan di rumah (Juniman, 2017). Saat ini, wisatawan lebih suka jika ke suatu daerah memakan makanan kuliner khas daerah tersebut (Nararya, 2019). Kondisi ini menjadikan makan tidak hanya sebagai kebutuhan untuk memenuhi rasa lapar saja, tetapi berubah menjadi wisata kuliner. Saat ini, pengembangan dalam strategi bisnis tidak lagi berdasarkan pada produk melainkan pada konsumen, apa yang konsumen inginkan saat ini dan apa yang konsumen butuhkan (Nararya, 2019). Menurut Liu \& Tse (2018), kualitas makanan, kualitas layanan, suasana dan harga merupakan faktor penting bagi pelanggan saat makan di rumah makan. Oleh karena itu, pelaku usaha harus memerhatikan pelanggan, terutama dalam kebutuhan dan keinginan pelanggan. Pelaku usaha perlu mementingkan loyalitas pelanggan di mana pelanggan merasa puas dengan pengalaman yang telah diberikan. Menurut Chao (2015), untuk menciptakan loyalitas pelanggan, pelaku usaha harus menggunakan persepsi tentang kepuasan. Hal ini seperti yang dilakukan oleh rumah makan Si Bolang yang menerapkan konsep pemasaran modern. Perubahan gaya hidup membuat kegiatan pemasaran industri rumah makan fokus pada suasana, desain, keramahan, dan faktor intangible lainnya yang fokus pada pemberian pengalaman yang tak terlupakan kepada konsumen. Memori terhadap pengalaman yang diberikan akan terukir di perasaan konsumen dan memengaruhi perilaku konsumen dalam jangka panjang (Dewi, 2019). Strategi ini disebut sebagai pemasaran pengalaman atau experiential marketing (Schmitt, 1991). 
Rumah Makan Si Bolang merupakan tempat wisata kuliner yang ada di Kampung Wisata Bontang Kuala (Dewi, 2019). Rumah Makan Si Bolang dapat dikatakan menarik dan berbeda karena lokasi yang berada di atas laut langsung bermodel restauran panggung yang santai dan menyediakan makananmakanan khas Bontang. Rumah Makan Si Bolang merupakan pencetus pertama makanan khas kota Bontang yaitu Gami Bawis yang tercatat pernah mengikuti promosi kuliner daerah yang diselenggarakan di Den Hag Belanda, lalu meraih juara di beberapa kompetisi yaitu juara 1 di Festival Benua Etam pada 2011, kemudian juara 1 di Festival Kuliner Tradisional Region Kalimantan Timur pada 2014, lalu masuk ke dalam nominasi 10 besar di Anugerah Pesona Indonesia tahun 2017 (Dewi, 2019). Penerapan strategi experiential marketing menurut Schmitt (1991) merupakan perpaduan pemasaran yang melibatkan emosional konsumen dengan meningkatkan pengalaman pribadi pada produk serta layanan. Seperti rumah makan Si Bolang memiliki penyajian yang memberi kesan langsung pada mata dan cita rasa pelanggan dalam penyajian makanan diletakkan ke dalam cobek tanah liat lalu dibakar dan dipanaskan di atas pembakaran bersama Sambal Gami khas Bontang yang meluapluap pada saat dihidangkan (Dewi, 2019). Suasana di atas laut yang tenang dengan berhembusnya angin laut yang lembut memanjakan siapapun yang berkunjung dan menyantap di rumah makan Si Bolang dengan pemandangan laut, pemandangan hutan Mangrove, pemandangan perumahan kayu yang terletak di atas laut, dan konsep rumah makan yang cozy casual memberikan pengalaman yang dapat menimbulkan kepuasan pelanggan yang berkunjung (Dewi, 2019).

Menurut Irawan (2008), terdapat faktor pendorong kepuasan salah satunya yaitu faktor emosional. Rasa bangga dan percaya yang terjadi terhadap pelanggan merupakan nilai emosi yang memberikan sensasi dan pengalaman pelanggan. Menurut Yeh et al. (2019), menggunakan experiential marketing untuk meningkatkan kepuasan pelanggan dan peningkatan kepuasan pelanggan akan memperkuat niat pelanggan untuk mengunjungi kembali. Melalui konsep experiential marketing dari Schmitt (1991), terdapat lima tipe modul pengalaman strategis (SEMs) dari experiential marketing yaitu sense, feel, think, act dan relate. Menerapkan experiential marketing, pelaku usaha dapat menciptakan hubungan yang baik dan berlangsung lama dengan konsumen. Penjelasan tersebut sesuai dengan Araci et al. (2017) dan Chen et al. (2019) bahwa pemasaran berdasarkan pengalaman terdapat efek yang positif pada kepuasan pelanggan. Terblanche (2018) dan Ihtiyar et al.(2018) menyatakan kepuasan dapat menimbulkan niat untuk mengunjungi kembali. Menurut Huang et al.(2015), experiential marketing berpengaruh signifikan pada niat mengunjungi kembali. Lekstutytè (2016) experiential marketing tidak berpengaruh signifikan pada kepuasan pelanggan. Kepuasan secara keseluruhan tidak memediasi hubungan antara pengalaman dan niat mengunjungi kembali Richardson et al.(2019) dan Jeon (2013) pengalaman tidak berpengaruh signifikan pada niat mengunjungi kembali.

Penelitian ini juga mengembangkan penelitian Terblanche (2018) untuk menyelidiki variabel yang membentuk pengalaman pelanggan di industri lain seperti restaurant, serta memerluas dimensi dan menghasilkan hasil yang berbeda (Fernandes \& Cruz 2016). Beberapa studi sebelumnya tidak secara empiris memvalidasi pernyataan yang digunakan untuk mengukur experiential marketing (Schmitt, 1991; Musa et al., 2015; Wang et al., 2016; Manthiou et al., 2016).

Penelitian ini memiliki tujuan untuk membahas pengaruh dari experiential marketing sebagai strategi pemasaran pada kepuasan konsumen dan dapat menimbulkan perilaku berkunjung kembali ke rumah makan.

\section{KAJIAN PUSTAKA DAN PENGEMBANGAN HIPOTESIS}

\section{Perilaku Konsumen}

Pengertian perilaku konsumen menurut Kotler \& Keller (2008) merupakan pengkajian mengenai seseorang baik secara perorangan, kelompok, maupun dalam formasi besar untuk menentukan, memakai, memanfaatkan hingga membuang produk, layanan, dan gagasan guna memuaskan kepentingan dan keinginan masing-masing. Menurut teori Blackwell et al. (2001), pengambilan keputusan konsumen memiliki beberapa proses yang terdiri dari lima tahap yaitu tahap pengenalan masalah, tahap penelusuran informasi, tahap evaluasi alternatif, tahap pilihan, dan tahap hasil. Setelah konsumen melakukan pilihan, selanjutnya tahapan hasil. Konsumen dapat merasakan hasil dari pilihan 
yang telah dipilih. Hasil tersebut seperti merasakan kepuasan atau ketidakpuasan terhadap suatu pilihannya sebagai pengalaman ketika menggunakan merek. Jika konsumen merasakan kepuasan maka hal yang terjadi akan menimbulkan aktivitas pembelian ulang. Faktor yang memengaruhi loyalitas menurut Gaffar (2007) yaitu kepuasan, ikatan emosi, kemudahan, pengalaman terhadap perasaan dan kepercayaan. Menurut Irawan (2008), terdapat lima faktor pendorong kepuasan yaitu kualitas layanan, kualitas produk, biaya dan kemudahan, harga, dan faktor emosional. Faktor emosional menciptakan pengalaman terhadap produk atau jasa pada pelanggan. Hal ini memiliki hubungan langsung terhadap experiential marketing yang disebabkan oleh emosional yang muncul dalam diri pelanggan, selanjutnya memunculkan adanya rangsangan yang diterima.

\section{Experiential Marketing}

Terdapat lima strategi atau dimensi experiential marketing menurut Schmitt (1991) yaitu sense, feel, think, act, dan relate. Menurut Schmitt (1991), pengalaman adalah insiden yang terjadi sebagai timbal balik pada sejumlah stimulus seperti dengan pemasaran sebelum dan setelah pembelian atau penerimaan. Schmitt (1991) experiential marketing dapat diartikan sebagai pengalaman yang dialami secara pribadi oleh individu dalam menerima stimulus ada saat sebelum atau sesudah pembelian ketika menerima suatu produk baik barang atau layanan dalam pengalaman emosi yang dirasakan hingga menyentuh perasaan. Penelitian ini menggunakan lima indikator, yaitu sense, feel, think, act, dan relate dengan butir pernyataan untuk mengukur experiential marketing. Sense yaitu penyajian yang menggugah selera, rasa makanan yang enak, penyajian makanan yang segar, feel yaitu suasana yang akrab, senang berada di rumah makan, think yaitu menu yang menambah keingin tahuan akan asal usul makanan, act yaitu konsep rumah makan yang sesuai, relate yaitu berada dirumah makan yang tepat (Araci et al., 2017). Menurut Lekstutyte (2016), terdapat lima indikator sense, feel, think, act, dan relate dengan butir pernyataan yaitu terdapat aroma yang enak dari rumah makan, makanan yang segar, perabotan yang bersih, merasa senang berada di rumah makan, merasa nyaman dengan suasana.

Mengukur experiential marketing dalam penelitian ini menggunakan lima indikator, yaitu: sense, feel, think, act, dan relate dari Schmitt (1991) dengan pernyataan seperti penyajian makanan yang menggugah selera, rasa makanan, kesegaran makanan, beragam menu, aroma rumah makan, kebersihan rumah makan, suasana rumah makan, asal usul pembuatan makanan, menghargai makanan khas daerah, konsep rumah makan, makan di rumah makan sebagai gaya hidup, merasa berada di rumah makan yang tepat. Hal ini didukung Chao (2015) bahwa experiential marketing berpengaruh terhadap kepuasan pelanggan, begitu pula dengan penelitian dari Yeh et al.(2019) mendapat hasil bahwa terdapat pengaruh signifikan antara experiential marketing dan kepuasan konsumen. Chen et al. (2019) menunjukkan hasil pengaruh signifikan antara experiential marketing dan kepuasan konsumen.

\section{Customer Satisfaction}

Kepuasan menurut Schiffman \& Wisenblit (2015) merupakan rasa puas yang mengarah pada tanggapan konsumen tentang kinerja suatu produk atau layanan yang diterima dalam hubungannya dengan harapan mereka. Menurut Kotler \& Keller (20008), kepuasan secara umum merupakan perasaan senang atau rasa kecewa seseorang yang timbul karena membandingkan kinerja yang dipersepsikan produk baik barang atau jasa dengan ekspektasi seseorang. Kepuasan pelanggan memiliki beberapa konsep yang terdiri dari tujuan perusahaan, kebutuhan pelanggan terhadap jasa, harapan pelanggan terhadap jasa, dan tingkat kepuasan konsumen.

Menurut Fernandes \& Cruz (2016), terdapat beberapa indikator kepuasan pelanggan yaitu puas dengan pelayanan yang diberikan, puas dengan produk yang disajikan, perasaan puas datang ke tempat. Menurut Lekstutytė (2016), terdapat beberapa indikator kepuasan pelanggan yaitu secara keseluruhan penalaman yang diberikan lebih baik dari yang diharapkan, puas dengan keputusan makan di rumah makan ini, puas dengan rumah makan ini, pengalaman yang diberikan membuat suasana hati bagus. Araci et al.(2017) berpendapat bahwa indikator kepuasan pelanggan yaitu pelayanan rumah makan ini selalu sesuai dengan harapan, puas dengan pelayanan, pelayanan rumah makan ini selalu di atas harapan, selalu mendapatkan pelayanan tepat waktu. Mengukur kepuasan pelanggan dalam penelitian ini menggunakan empat indikator yaitu puas makan di rumah makan, puas dengan pelayanan rumah 
Nourissa Dinda Syachadi \& Widyastuti. Pengaruh Experiential Marketing terhadap Niat Mengunjungi Kembali di Rumah Makan dengan Kepuasan Konsumen sebagai Variabel Mediasi

makan, pengalaman membuat suasana hati yang senang, pengalaman lebih baik dari yang diharapkan. Hal tersebut didukung Han et al. (2019), Araci et al. (2017), Ihtiyar et al. (2018), dan Terblanche (2018) bahwa kepuasan pelanggan dapat menimbulkan niat repatronase atau niat untuk berkunjung kembali.

\section{Revisit Intention}

Niat mengunjungi kembali atau revisit intention diambil dari repurchase intention yang terdapat dalam beberapa perilaku post purchase behavior atau perilaku pasca-pembelian. Konsumen akan merasa puas dan melakukan kunjungan kembali di waktu mendatang dan juga kepuasan merupakan faktor utama dari niat mengunjungi kembali (Antón et al., 2018). Menurut Huang et al. (2015), revisit intention merupakan kesediaan pelanggan untuk mengunjungi dan terus menggunakan produk atau jasa yang sama seperti sebelumnya. Stylos et al. (2016) menjelaskan pengertian revisit intention atau niat mengunjungi kembali sebagai niat seseorang mengunjungi suatu tempat yang sama untuk kedua kalinya dalam jangka waktu tertentu. Berdasarkan beberapa teori tersebut revisit intention adalah evaluasi yang dilakukan oleh pelanggan atau pengunjung mengenai pengalaman atau nilai yang dirasakan dan kepuasan secara keseluruhan untuk melakukan kunjungan kembali kesuatu tempat atau destinasi di masa yang akan datang. Penelitian ini mengukur niat mengunjungi kembali menggunakan indikator dari Antón et al. (2018) terdapat indikator dari niat mengunjungi kembali yaitu akan berkunjung kembali di waktu yang akan datang. Menurut Ihtiyar et al. (2018), terdapat beberapa indikator dari niat mengunjungi kembali yaitu menjadi pilihan pertama, akan terus membeli di waktu yang akan datang dan menurut Araci et al. (2017), terdapat beberapa indikator dari niat mengunjungi kembali yaitu akan datang kembali, tidak pergi ke rumah makan lain, rumah makan ini menjadi pilihan pertama. Mengukur niat mengunjungi kembali dalam penelitian ini menggunakan tiga indikator yaitu akan terus datang di waktu mendatang, menjadi pilihan pertama ketika membutuhkan layanan makanan, berniat mengunjungi kembali dalam waktu dekat. Hal tersebut didukung Han et al.(2019) dan Ihtiyar et al. (2018) bahwa experiential marketing berpengaruh signifikan baik secara langsung maupun tidak langsung pada niat mengunjungi kembali. Ihtiyar et al. (2018), Nurcahyo (2016), dan Han et al. (2019) menunjukkan bahwa kepuasan menjadi variabel mediasi antara variabel experiential marketing $(\mathrm{X})$ dan revisit intention $(\mathrm{Y})$. Kepuasan yang dirasakan oleh konsumen sesuai dengan harapan yang diinginkan dan pada saat konsumen merasakan kepuasan yang positif maka dapat memeroleh hubungan yang baik antara konsumen dan pihak pengelola, sehingga tercipta kunjungan ulang.

\section{Hubungan antar Variabel}

Teori yang dikemukakan oleh Irawan (2008) menyatakan bahwa terdapat lima faktor pendorong kepuasan yaitu kualitas produk, kualitas layanan, biaya dan kemudahan, harga, dan emosional. Pada kelima faktor pendorong tersebut terdapat faktor emosional yang ada di experiential marketing. Pengalaman dari experiential marketing yang dialami secara pribadi dalam menerima rangsangan yang dirasakan sehingga menyentuh emosi pelanggan (Schmitt, 1991). Menurut Gaffar (2007), kepuasan merupakan perbandingan antara harapan sebelum dilakukannya pembelian terhadap apa yang saat ini dirasakan. Hal tersebut menunjukkan experiential marketing memengaruhi kepuasan konsumen pada rumah makan Si Bolang. Hal tersebut juga didukung oleh Chao (2015), Yeh et al. (2019), Chen et al.(2019), dan Nurcahyo (2016) bahwa experiential marketing memiliki pengaruh yang signifikan positif terhadap kepuasan. Kepuasan konsumen akan semakin meningkat setelah merasakan kesesuaian ekspektasi yang dirasakan melalui experiential marketing atau pengalaman yang telah diberikan.

\section{H1: Experiential marketing berpengaruh signifikan terhadap kepuasan konsumen.}

Teori Blackwell et al.(2001) menyatakan bahwa jika konsumen merasakan kepuasan, konsumen akan membeli ulang. Revisit intention merupakan adopsi dari repurchase intention yang termasuk ke dalam salah satu perilaku post purchase behavior atau perilaku pasca-pembelian (Antón et al., 2018). Sejalan dengan Antón et al.(2018), konsumen yang merasa puas akan melakukan kunjungan ulang di masa yang akan datang dan juga kepuasan merupakan anteseden urama dari niat mengunjungi kembali. Teori tersebut didukung dengan hasil penelitian yang dilakukan oleh penelitian terdahulu Han et al. (2019), Araci et al. (2017), Ihtiyar et al. (2018), dan Terblanche (2018) yang hasilnya bahwa kepuasan pelanggan dapat menimbulkan niat repatronase atau niat untuk berkunjung kembali. 
H2: Kepuasan konsumen berpengaruh signifikan terhadap niat mengunjungi kembali.

Huang et al.(2015) menyatakan bahwa repurchase intention adalah kesediaan pelanggan untuk terus menggunakan produk atau jasa yang sama dengan jumlah yang sama seperti sebelumnya dan revisit intention merupakan kesediaan pelanggan untuk mengunjungi kembali destinasi atau tempat yang sama. Menurut Stylos et al. (2016), revisit intention atau niat mengunjungi kembali adalah keinginan untuk berkunjung ke destinasi atau tempat yang sama untuk kedua kalinya dalam jangka waktu tertentu. Teori tersebut selaras dengan penelitian Han et al.(2019) dan Ihtiyar et al.(2018) bahwa experiential marketing berpengaruh signifikan baik secara langsung maupun tidak langsung pada niat mengunjungi kembali. Hal tersebut menunjukkan ketika pengunjung menerima pengalaman yang dirasakan hingga membentuk pikiran positif, mereka akan bersedia datang kembali di waktu dekat.

H3: Experiential marketing berpengaruh signifikan terhadap niat mengunjungi kembali.

Ketika konsumen merasakan kepuasan, konsumen akan berkunjung kembali di waktu yang akan datang. Hal ini didukung Ihtiyar et al.(2018), Nurcahyo (2016), dan Han et al.(2019) yang menyatakan bahwa kepuasan menjadi variabel mediasi antara experiential merkting dan revisit intention. Kepuasan yang diterima oleh konsumen sesuai dengan ekspektasi yang diharapkan ketika konsumen merasakan kepuasan akan menimbulkan keharmonisan antara konsumen dan pihak pengelola rumah makan. Hal tersebut akan menciptakan kunjungan ulang di waktu yang akan datang.

H4: Kepuasan konsumen memediasi pengaruh experiential marketing terhadap niat mengunjungi kembali.

\section{METODE PENELITIAN}

Jenis penelitian ini adalah kuantitatif dengan karakteristik responden yang berusia dari 18 hingga 50 tahun yang tahu dan pernah mengunjungi rumah makan Si Bolang lebih dari 2 kali dalam kurun waktu 6 bulan terakhir. Penelitian ini meneliti variabel experiential marketing, customer satisfaction dan revisit intention. Sumber data dalam penelitian ini adalah data primer dan sekunder. Data primer berasal dari pengumpulan data secara langsung berupa hasil kuesioner yang disebarkan secara online menggunakan Google Form. Penelitian ini juga menggunakan data sekunder untuk melengkapi kebutuhan data penelitian seperti melalui artikel, jurnal, buku, hingga situs yang berkaitan dengan informasi yang sedang dibutuhkan. Data dilakukan uji validitas, reliabilitas, uji normalitas, uji linieritas, uji multikolinieritas. Teknik analisis data mengunakan path analisis dengan SPSS Versi 25 dan Aplikasi Sobel Test (1982).

\section{HASIL DAN PEMBAHASAN}

\section{Karakteristik Responden}

Total responden 200 dengan karakteristik jenis kelamin di dominasi laki-laki dengan jumlah 56,5\% atau dengan jumlah 113 responden. Karakteristik berdasarkan usia dominan usia 18-25 tahun dengan jumlah 179 atau sebesar 89,5\% untuk karakteristik status dominan oleh mahasiswa dengan jumlah 123 atau 61,5\% dan berdasarkan frekuensi kunjungan kerumah makan Si Bolang dalam kurun waktu 6 bulan terakhir lebih dari 2 kali dengan jumlah 139 atau $69,5 \%$.

\section{Hasil Analisis Deskriptif}

Jawaban responden telah dianalisis untuk semua variabel experiential marketing, kepuasan konsumen dan niat mengunjungi kembali menunjukkan hasil yang baik pada masing-masing indikator. Experiential marketing, kepuasan konsumen, dan niat mengunjungi kembali secara urut memiliki nilai rata-rata yaitu sebesar 3,931; 4,025; dan 3,95. Semua variabel dengan nilai tersebut menunjukkan hasil yang baik dengan jawaban responden rata-rata menjawab setuju. 
Nourissa Dinda Syachadi \& Widyastuti. Pengaruh Experiential Marketing terhadap Niat Mengunjungi Kembali di Rumah Makan dengan Kepuasan Konsumen sebagai Variabel Mediasi

\section{Uji Validitas}

Uji validitas dan reliabilitas telah dilakukan menggunakan sampel dari 200 responden terhadap 3 variabel dengan total 23 pernyataan pada Tabel 1 .

\section{Tabel 1.
HASIL UJI VALIDITAS DAN RELIABILITAS}

\begin{tabular}{lc}
\hline Variabel dan Pernyataan & Coefficient Correlation \\
\hline Experiential Marketing (Cronbach's Alpha =0.871) & \\
Penyajian makanan menggugah selera & 0.609 \\
Rasa makanan yang enak & 0.631 \\
Makanan yang segar & 0.655 \\
Beragam menu pilihan & 0.548 \\
Aroma yang enak dari rumah makan & 0.584 \\
Tempat yang bersih & 0.426 \\
Bahagia berada dirumah makan & 0.607 \\
Suasana seperti makan dirumah & 0.561 \\
Menu yang disajikan membuat ingin tahu proses pembuatan makanan tersebut & 0.496 \\
Menu yang disajikan membuat ingin tahu asal usul makanan tersebut & 0.603 \\
Pensaran dengan rumah makan melekat dengan alam & 0.610 \\
Suka makan dirumah makan & 0.566 \\
Lebih menghargai makanan khas daerah & 0.427 \\
Konsep rumah makan yang cocok & 0.701 \\
Makan di rumah makan ini bagian dari gaya hidup & 0.617 \\
Berada di rumah makan yang tepat & 0.716 \\
Customer Satisfaction (Cronbach's Alpha =0.750) & \\
Puas makan di rumah makan Si Bolang & 0.682 \\
Pengalaman yang diberikan lebih baik dari yang diharapkan & 0.820 \\
Pengalaman yang didapatkan membuat suasana hati senang & 0.785 \\
Puas dengan pelayanan rumah makan Si Bolang & 0.737 \\
Revisit Intention (Cronbach's Alpha $=0.746)$ & \\
Akan terus datang ke rumah makan Si Bolang di waktu mendatang & 0.961 \\
Rumah makan Si Bolang pilihan pertama & 0.815 \\
Berniat mengunjungi rumah makan dalam waktu dekat & 0.763 \\
\hline Sumber Data diolah (2021)
\end{tabular}

Sumber: Data diolah (2021)

Tabel 1 menujukkan seluruh pernyataan dikatakan valid karena $\mathrm{R}$ hitung atau coefficient correlation memiliki jumlah nilai yang lebih tinggi daripada $\mathrm{R}$ tabel bernilai 0,138 . Seluruh pernyataan dalam penelitian ini adalah valid dan bisa digunakan sebagai alat ukur penelitian.

\section{Uji Reliabilitas}

Berdasarkan Tabel 1, semua variabel memiliki nilai Cronbach Alpha untuk lebih tinggi dari nilai kritis yang ada sebesar 0,60. Sehingga, data reliabel dan layak untuk dilakukan pengujian selanjutnya.

\section{Uji Normalitas}

Uji normalitas one-sample Kolmogorov-smirnov test signifikansi senilai 0,074 dan hasil tersebut lebih tinggi dari 0,05 . Nilai residual berdistribusi normal. Setiap responden menjawab pernyataan berbedabeda menunjukkan penyebaran dilakukan secara merata dan tidak mengendalikan responden dalam menjawab pernyataan. Dari hasil tersebut, data layak digunakan untuk estimasi berikutnya.

\section{Uji Linieritas}

Uji linieritas digunakan untuk mengetahui data linier atau tidak. Ketentuan dari uji linier ini jika nilai P atau nilai signifikansinya kurang dari 0,05 , hasil perhitungan dikatakan linier. Nilai signifikansi pada uji linieritas menunjukkan hubungan experiential marketing terhadap kepuasan dengan nilai 
probabilitas 0,000 berada pada rentang kurang dari 0,05 . Hubungan kepuasan pada revisit intention dengan probabilitas sejumlah 0,000 berada pada rentang kurang dari 0,05 . Hubungan experiential marketing kepada revisit intention dengan probabilitas sejumlah 0,000 berada pada rentang kurang dari 0,05 , maka uji linieritas terbukti kebenarannya.

\section{Uji Multikolinieritas}

Uji mulikolinieritas memiliki fungsi untuk menyelidiki adanya korelasi antara variabel bebas pada model regresi. Model regresi yang baik seharusnya tidak terjadi korelasi. Ada atau tidaknya multikolinieritas dapat dilihat dari hasil nilai Tolerance dan VIF. Apabila nilai toleransi >0,10 dikatakan tidak terjadi multikolinieritas, kemudian jika hasil VIF memiliki jumlah nilai kurang dari 10,00 terbukti tidak terjadi multikolinieritas (Ghozali, 2018).

Hasil multikolinieritas, variabel bebas tidak ada yang memiliki nilai toleransi kurang dari 0,10 karena nilai Tolerance variabel experiential marketing sejumlah 0,597 dan kepuasan sejumlah 0,587. Maka tidak ada korelasi antar variabel independen. Hasil pengolahan data pada variance inflation factor (VIF) memeroleh nilai VIF >10,00 karena nilai VIF variabel experiential marketing sebesar 1,703 dan variabel kepuasan sebesar 1,703. Sehingga, tidak ada multikolinieritas antar variabel independen dalam model regresi.

\section{Uji Analisis Model}

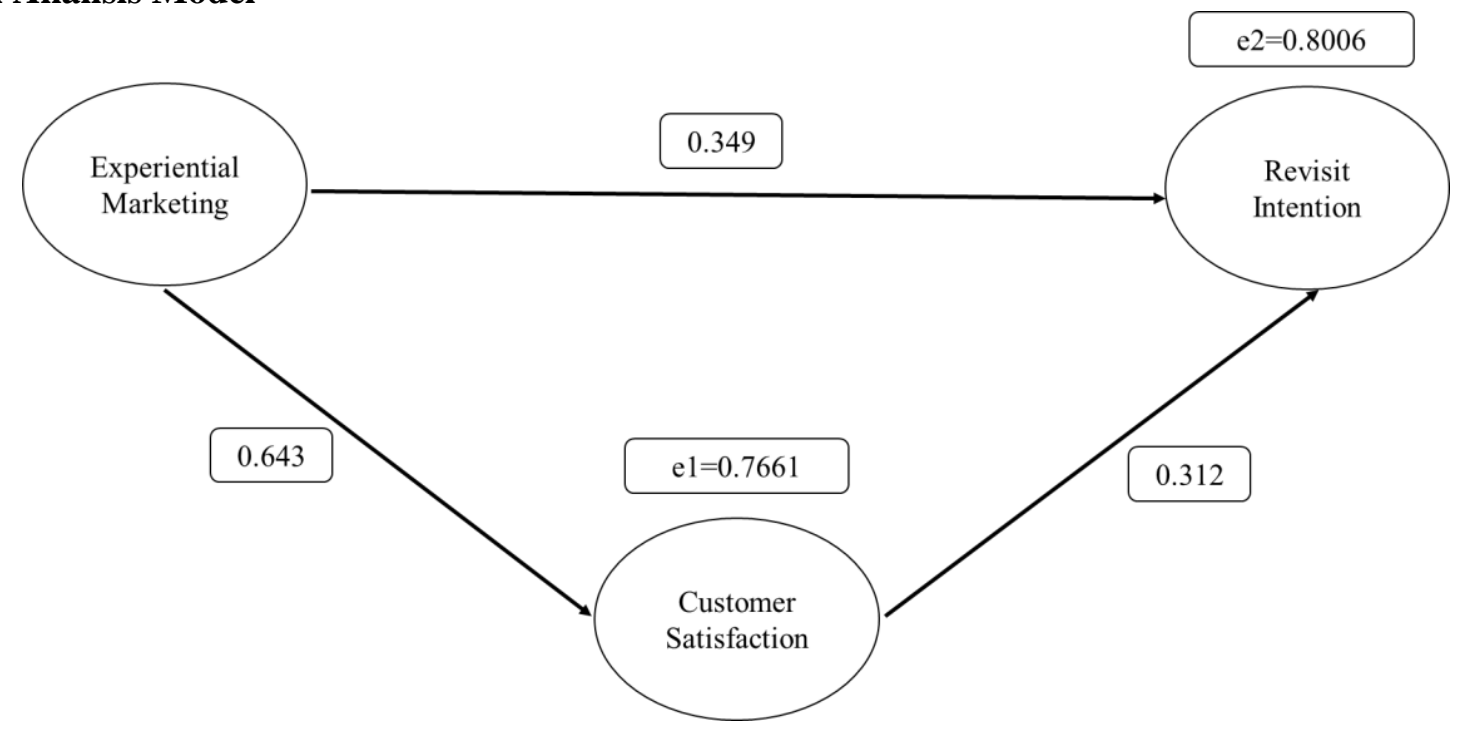

Sumber: Data diolah (2021)

\section{Gambar 1. DIAGRAM JALUR}

Gambar 1 dapat dikonversikan ke dalam persamaan model struktural. Menurut Ghozali, (2018), perhitungan e 1 dan e2 melalui rumus $\mathrm{e}=\sqrt{\left(1-r^{2}\right.}$. $\mathrm{R}$ square model 1 bernilai 0.413 , di mana sumbangan pengaruh experiential marketing $(\mathrm{x})$ terhadap consumer satisfaction $(\mathrm{z})$ sebesar $41,3 \%$. Sisanya sebesar $58 \%$ berupa partisipasi dari variabel lain yang tidak termasuk dalam penelitian ini. Nilai e1 sebesar 0.7661 . Tabel coeffisient $\mathrm{X}=0.000$ di mana $<0.05$, maka regresi variabel experiential marketing $\rightarrow$ customer satisfaction berpengaruh signifikan. Selanjutnya, R square pada model 2 bernilai 0.359 . Hal ini menunjukkan partisipasi experiential marketing dan customer satisfaction pada revisit intention sebesar $35.9 \%$, kemudian sisanya sebesar $64.1 \%$ merupakan partisipasi dari variabel lain yang tidak diteliti dalam penelitian ini. Nilai e2 $=\sqrt{(1-0.359}$ sebesar 0.8006. Lalu, berdasarkan output model 2, variabel $\mathrm{X}$ memperoleh hasil signifikansi dengan jumlah nilai 0,000 dan $\mathrm{Z}$ dengan jumlah nilai 0,000 di mana $<0.05$ sehingga variabel experiential marketing dan customer satisfaction berpengaruh signifikan terhadap revisit intention. 
Nourissa Dinda Syachadi \& Widyastuti. Pengaruh Experiential Marketing terhadap Niat Mengunjungi Kembali di Rumah Makan dengan Kepuasan Konsumen sebagai Variabel Mediasi

Tabel 2

\section{STANDARDIZED REGRESSION WEIGHTS}

\begin{tabular}{lll}
\hline Hubungan antar Variabel & Estimate & P/Sig \\
\hline Experiential Marketing $\rightarrow$ Customer Satisfaction & 0.643 & 0.000 \\
Customer Satisfaction $\rightarrow$ Revisit Intention & 0.312 & 0.000 \\
Experiential Marketing $\rightarrow$ Revisit Intention & 0.349 & 0.000 \\
\hline Sun
\end{tabular}

Sumber: Data diolah penulis (2021)

Hasil persamaan path analysis pada Tabel 2 menunjukkan variabel experiential marketing terhadap kepuasan berpengaruh positif dengan menghasilkan koefisien jalur yaitu 0,643. Variabel kepuasan konsumen menunjukkan pengaruh positif terhadap variabel niat mengunjungi kembali menghasilkan nilai koefisien jalur yaitu 0,312 dan variabel experiential marketing terhadap variabel niat mengunjungi kembali memiliki pengaruh positif dengan nilai koefisien jalur yaitu 0,349 .

\section{Koefisien Determinasi}

Berdasarkan koefisien jalur pada Gambar 1, besarnya pengaruh custumer satisfaction dikarenakan kontribusi variabel experiential marketing sebesar 0,413. Artinya, experiential marketing berpengaruh terhadap customer satisfaction sebesar $41,3 \%$. Sisanya disebabkan oleh variabel lain di luar penelitian ini. Variabel revisit intention memiliki pengaruh besar karena kontribusi experiential marketing dan customer satisfaction dengan hasil 0.359. Variabel experiential marketing dan customer satisfaction berpengaruh terhadap revisit intention dengan hasil 35.9\%, sedangkan sisanya disebabkan oleh variabel lain di luar penelitian ini.

\section{Uji Hipotesis}

Analisis pengaruh setiap variabel di Tabel 2 menujukkan nilai signifikansi pada setiap variabel 0,000 lebih kecil dari 0,05 dapat dikatakan secara langsung bisa berpengaruh secara signifikan pada setiap hubungan variabel. Experiential marketing berpengaruh terhadap customer satisfaction dengan nilai 0.643. Pengaruh experiential marketing ke revisit intention memeroleh nilai 0.349. Pengaruh customer satisfaction terhadap revisit intention sebesar 0.312. Jika tanpa melalui variabel kepuasan (Z) pengaruh tidak langsung dari variabel experiential marketing terhadap revisit intention memeroleh nilai 0.201 yang didapat dari perhitungan perkalian antara nilai beta $\mathrm{X}$ terhadap $\mathrm{Z}$ dan nilai beta $\mathrm{Z}$ terhadap $\mathrm{Y}$. selanjutnya nilai pengaruh dari variabel experiential marketing $(\mathrm{X})$ terhadap loyalitas $(\mathrm{Y})$ yaitu 0.349 $+0.201=0.55$. Hasil tersebut mampu menjelaskan pengaruh experiential marketing $(X)$ pada customer satisfaction $(\mathrm{Z})$ memiliki hasil yang lebih besar daripada hasil pengaruh langsung experiential marketing (X) pada revisit intention (Y). Variabel customer satisfaction tidak menjadi variabel bebas, akan tetapi variabel customer satisfaction dapat menjadi variabel mediasi dan variabel kepuasan tidak mampu dijadikan sebagai variabel bebas.

\section{Uji Mediasi}

Hasil uji mediasi terbukti berhubungan secara keseluruhan atau (parsial mediating). Hal tersebut dilihat dari variabel experiential marketing berpengaruh positif dan signifikan terhadap variabel customer satisfaction. Variabel customer satisfaction berpengaruh positif dan signifikan terhadap variabel revisit intention dan variabel experiential marketing berpengaruh positif dan signifikan terhadap revisit intention. Melalui hasil analisis tersebut dapat memberikan penjelasan bahwa mediasi terbukti secara berhubungan keseluruhan atau parsial (partially mediated) dengan hasil koefisien dari variabel experiential marketing $(\mathrm{X})$ terhadap revisit intention $(\mathrm{Y})$ memiliki nilai lebih rendah dibandingkan variabel experiential markekting $(\mathrm{X})$ terhadap customer satisfaction $(\mathrm{Z})(\mathrm{X} \rightarrow \mathrm{Y}=0.349 ; \mathrm{X} \rightarrow \mathrm{Z}=$ 0.643). Dari pengolahan data, variabel bebas secara langsung dapat berpengaruh tanpa melibatkan adanya mediator. Hasil dari pengujian uji mediasi ini mendukung penelitian terdahulu bahwa efek langsung positif dari pengalaman pada variabel tetap menunjukkan mediasi parsial serta efek tidak langsung positif melalui kepuasan pelanggan (Araci et al., 2017). 


\section{Sobel Test}

Sobel test berfungsi untuk menguji signifikansi dari koefisien efek tidak langsung atau mediasi. Menurut Ghozali (2018), sobel test dapat dilakukan dengan menggunakan Sobel (1982) yang ada di website uji sobel test. Hasil sobel test dapat dilihat pada Tabel 3.

Tabel 3.

\section{SOBEL TEST RESULT}

\begin{tabular}{llll}
\hline & Test Statistics & Std.Error & P-Value \\
\hline Sobel Test & 3.9555 & 0.0138 & 0.000 \\
\hline Sub
\end{tabular}

Sumber: Data diolah penulis (2021)

Tabel 3 menunjukkan hasil dari probabilitas value experiential marketing terhadap revisit intention melalui customer satisfaction adalah 0,000 di mana variabel customer satisfaction dapat memediasi antara experiential marketing dan revisit intention. Sehingga, sobel test dapat diterima.

Penelitian ini didominasi dengan responden yang berusia 18-25 tahun dengan status sebagai karyawan dengan jumlah 40 dan mahasiswa dengan jumlah 123 responden dikarenakan pada rentang usia tersebut responden lebih suka untuk berkumpul, makan bersama, bersantai, dan melepas penat. Responden didominasi oleh laki-laki yang berkunjung lebih dari 2 kali dengan total frekuensi kunjungan 113 disebabkan laki-laki cenderung suka berkumpul dengan jumlah yang banyak dan suka memilih tempat dengan konsep santai seperti rumah makan Si Bolang ini. Rata-rata responden menjawab setuju pada variabel experiential marketing dengan total rata-rata 3,931 yang menyatakan bahwa rata-rata responden merasa bahagia makan di rumah makan Si Bolang, memakan makanan yang enak, segar dan nyaman karena memiliki tempat yang bersih. Responden juga puas dengan menjawab setuju dari pernyataan variabel customer satisfaction dengan total rata-rata 4,025 menyatakan bahwa responden puas makan dirumah makan Si Bolang, pengalaman yang diberikan lebih baik dari yang diharapkan, pengalaman yang didapatkan membuat suasana senang, responden puas dengan pelayanan yang diberikan. Rata-rata jawaban responden setuju pada variabel revisit intention dengan total rata-rata 3,95, menyatakan responden akan terus datang ke rumah makan Si Bolang dalam waktu dekat. Responden menganggap rumah makan Si Bolang pilihan pertama disaat membutuhkan layanan makanan lagi, responden berniat mengunjungi kembali lagi rumah makan Si Bolang di waktu yang akan datang.

\section{Pengaruh Experiential Marketing terhadap Kepuasan Konsumen}

Hasil penelitian ini terdapat pengaruh signifikan dari variabel experiential marketing $(\mathrm{X})$ terhadap customer satisfaction (Z). Semakin meningkat experiential marketing, maka makin meningkat pula kepuasan yang dirasakan. Hasil ini dapat membuktikan hipotesis pertama yaitu experiential marketing berpengaruh signifikan terhadap kepuasan konsumen di rumah makan Si Bolang. Kepuasan konsumen akan meningkat setelah mendapatkan pengalaman yang sesuai dengan ekspektasi yang dirasakan melalui experiential marketing atau pengalaman yang telah diberikan.

Hasil ini mendukung penelitian Yeh et al. (2019), Chen et al. (2019), Han et al. (2019), dan Nurcahyo (2016) yang menyatakan bahwa experiential marketing memiliki pengaruh yang signifikan positif terhadap kepuasan. Pengaruh experiential marketing terhadap kepuasan memiliki hasil yang lebih besar dari pengaruh experiential marketing terhadap niat mengunjungi kembali karena pengelolaan rumah makan Si Bolang menggunakan experiential marketing sebagai strategi pemasaran dengan pengalaman yang dirasakan kala berkunjung. Perubahan gaya hidup yang terjadi menyebabkan strategi pemasaran sesuai dengan keinginan pelanggan yang memerhatikan suasana, desain, pelayanan, dan faktor intangible lainnya dengan menggunakan experiential marketing rumah makan Si Bolang dapat meningkatkan kepuasan pelanggan dengan menyentuh emosional pelanggan melalui pengalaman panca indera yaitu mata, lidah, telingga, dan kulit melalui produk dan layanan yang diberikan rumah makan Si Bolang. Pemasaran pengalaman yang didapat menciptakan kesamaan antara harapan dan kenyataan secara langsung di rumah makan Si Bolang. Sehingga, pengalaman yang diperoleh sebagai strategi pemasaran dari pengelola menghasilkan harapan yang tinggi dari konsumen. 
Dalam hal ini, jawaban tertinggi untuk indikator sense dengan pernyataan "Rumah makan Si Bolang menyajikan makanan yang menggugah selera makan" yang artinya rata-rata responden puas dengan penyajian makanan yang di hidangkan karena dapat meningkatkan selera makan responden. Jawaban tertinggi untuk indikator feel dengan pernyataan "Saya merasa bahagia berada di rumah makan Si Bolang" yang artinya rata-rata responden pada saat makan di rumah makan Si Bolang merasa senang dan puas dengan pelayanan yang diberikan. Jawaban tertinggi untuk indikator think dengan pernyataan "Rumah makan si Bolang memiliki lingkungan yang melekat dengan alam menambah rasa penasaran saya pada rumah makan ini" rata-rata responden ingin tahu keberadaan rumah makan Si Bolang yang berada di atas laut dan dikelilingi hutan Mangrove. Jawaban tertinggi untuk indikator act dengan pernyataan "Pengalaman yang diberikan mengubah gaya hidup saya untuk lebih menghargai makanan khas daerah" rata-rata responden menjadi suka, menikmati, dan menghargai makanan khas daerah yang di sajikan di rumah makan Si Bolang dengan penyajian yang menggugah selera makan. Jawaban tertinggi untuk indikator relate dengan pernyataan "Saya merasa berada di rumah makan yang tepat" yang artinya rata-rata responden pada saat makan di rumah makan Si Bolang merasa bahwa telah memilih tempat makan yang tepat. Dengan merasakan pengalaman pemasaran yang telah diberikan oleh rumah makan Si Bolang maka konsumen akan merasakan kepuasan makan di rumah makan Si Bolang sehingga akan meningkatkan kepuasan konsumen dari pengalaman yang dirasakan.

\section{Pengaruh Customer Satisfaction terhadap Niat Mengunjungi Kembali}

Hasil penelitian, terdapat pengaruh positif dan signifikan dari variabel customer satisfaction (Z) terhadap variabel revisit intention (Y). Semakin positif kepuasan yang diterima di rumah makan Si Bolang, maka semakin tinggi tingkat niat konsumen untuk mengunjungi rumah makan Si Bolang lagi. H2 dapat terbukti. Hasil ini selaras dengan pernyataan Antón et al. (2018) konsumen yang telah merasakan suatu kepuasan akan melakukan kunjungan ulang di waktu mendatang dan kepuasan merupakan anteseden utama dari niat mengunjungi kembali. Hasil tersebut mendukung penelitian Han et al. (2019), Araci et al. (2017), Ihtiyar et al. (2018), dan Terblanche (2018) bahwa kepuasan pelanggan dapat menimbulkan niat repatronase atau niat untuk berkunjung kembali. Jawaban tertinggi merupakan indikator puas makan di rumah makan dengan pernyataan "Saya puas makan di rumah makan Si Bolang" yang artinya rata-rata responden percaya di saat merasakan rasa puas setelah menerima layanan yang diberikan maka akan meningkatkan niat untuk berkunjung kembali ke rumah makan Si Bolang.

\section{Pengaruh Experiential Marketing terhadap Niat Mengunjungi Kembali}

Penelitian ini menunjukkan pengaruh langsung signifikan dari variabel experiential marketing (X) terhadap revisit intention (Y). H3 terbukti. Sejalan dengan teori Stylos et al. (2016), revisit intention atau niat berkunjung kembali sebagai keinginan seseorang untuk berkunjung ke suatu tempat yang sama kedua kalinya di waktu selanjutnya. Hasil tersebut selaras dengan Han et al.(2019) dan Ihtiyar et al.(2018) bahwa experiential marketing berpengaruh signifikan baik secara langsung maupun tidak langsung pada niat mengunjungi kembali. Saat pengunjung yang merasakan pengalaman yang menyenangkan di rumah makan Si Bolang, pikiran yang positif akan terbentuk, kemudian pengunjung akan bersedia untuk melakukan kunjungan kembali di waktu dekat. Pengaruh experiential marketing pada niat mengunjungi kembali memiliki hasil yang lebih tinggi karena pengalaman dapat secara langsung memberikan tindakan untuk mengunjungi kembali. Pemasaran pengalaman yang telah diterima akan menumbuhkan rasa emosional seperti perasaan positif ataupun perasaan negatif. Pengalaman pemasaran merupakan bagian yang sangat penting bagi konsumen karena sebelum melakukan niat untuk berkunjung kembali konsumen perlu merasakan pelayanan apa saja yang dapat diberikan oleh rumah makan Si Bolang agar konsumen mendapat gambaran, manfaat, dan nilai tambah dari suatu layanan untuk meningkatkan niat berkunjung kembali.

\section{Kepuasan sebagai Variabel Mediasi}

Penelitian ini membuktikan bahwa customer satisfaction $(\mathrm{Z})$ memiliki peran untuk memediasi antara variabel experiential marketing (X) dan revisit intention (Y). Pengalaman dapat memengaruhi konsumen untuk berkunjung lagi jika konsumen merasakan kepuasan dengan layanan yang diberikan. Ketika konsumen merasakan kepuasan maka konsumen akan berkunjung kembali di waktu yang akan datang. Ihtiyar et al. (2018), Nurcahyo (2016), dan Han et al. (2019) juga membuktikan bahwa kepuasan menjadi variabel mediasi antara variabel experiential marketing (X) dan revisit intention (Y) yang 
didukung hasil penelitian ini. Kepuasan yang dirasakan oleh konsumen sesuai dengan harapan yang diinginkan dan pada saat konsumen merasakan kepuasan yang positif maka dapat memeroleh hubungan yang baik antara konsumen dan pihak pengelola rumah makan Si Bolang, sehingga menciptakan kunjungan ulang.

\section{KESIMPULAN}

Hasil penelitian ini, terdapat pengaruh signifikan dari experiential marketing terhadap kepuasan konsumen pada rumah makan Si Bolang kemudian kepuasan konsumen memiliki pengaruh yang signifikan terhadap niat mengunjungi kembali di rumah makan si Bolang selanjutnya experiential marketing berpengaruh secara signifikan terhadap niat mengunjungi kembali di rumah makan Si Bolang dan kepuasan konsumen dapat memediasi pengaruh antara experiential marketing dan niat mengunjungi kembali.

Penelitian ini memiliki keterbatasan yaitu memfokuskan pelanggan yang sudah berkunjung lebih dari dua kali dalam waktu enam bulan terakhir kemudian sudut pandang penelitian ini berdasarkan hasil dari penerapan atau penggunaan experiential marketing pada rumah makan Si Bolang, dalam hal ini konsumen merasakan pengalaman pemasaran yang diberikan oleh rumah makan Si Bolang guna menumbuhkan rasa puas dalam bersantap di rumah makan Si Bolang. Penelitian selanjutnya diharapkan dapat dilakukan dengan menggunakan variabel lain seperti service innovation dan brand serta dapat menggunakan objek selain rumah makan dan wisata.

Implikasi dalam penelitian ini bagi pelaku usaha rumah makan si Bolang yaitu perlu adanya perhatian lebih pada penggunaan strategi experiential marketing. Pelaku usaha perlu meningkatkan pengalaman konsumen pada saat mengunjungi rumah makan Si Bolang seperti, peningkatan dalam cita rasa makanan, pengembangan menu, peningkatan dalam penyajian makanan, peningkatan konsep rumah makan yang disesuaikan dengan kebutuhan konsumen untuk bersantap dengan santai dan peningkatan pelayanan yang diberikan guna menambah rasa nyaman dalam bersantap seperti makan di rumah yang disesuaikan dengan keinginan konsumen. Pelaku usaha perlu memerhatikan strategi dalam memberikan pengalaman pada konsumen agar tumbuh rasa puas dan memberikan dorongan pada niat konsumen untuk melakukan kunjungan ulang pada waktu berikutnya.

\section{DAFTAR PUSTAKA}

Antón, C., Camarero, C., \& Laguna-García, M. (2018). Experience Value or Satiety? The Effects of the Amount and Variety of Tourists' Activities on Perceived Experience. Journal of Travel Research, 57(7), 920-935. https://doi.org/10.1177/0047287517727366

Araci, U. E., Bulut, Z. A., \& Kocak, N. (2017). the Relation Among Experiential Marketing, Customer Satisfaction, and Behavioral Intention: a Study on Food and Beverage Businesses. Economic and Social Development, 23rd International Scientific Conference on Economic and Social Development, 23(63), 361-371.

Blackwell, R., Miniard, P. W., \& Engel, J. (2001). Consumer Behavior (9th ed). Mason: South-Western Thomas Learning.

Chao, D. R.-F. (2015). The Impact of Experimental Marketing on Customer Loyalty for Fitness Clubs: Using Brand Image and Satisfaction as the Mediating Variables. The Journal of International Management Studies, 10(2), 52-60.

Chen, Y. C., Tsui, P. L., Chen, H. I., Tseng, H. L., \& Lee, C. S. (2019). A dining table without food: the floral experience at ethnic fine dining restaurants. British Food Journal, 122(6), 1819-1832. https://doi.org/10.1108/BFJ-08-2018-0541 
Nourissa Dinda Syachadi \& Widyastuti. Pengaruh Experiential Marketing terhadap Niat Mengunjungi Kembali di Rumah Makan dengan Kepuasan Konsumen sebagai Variabel Mediasi

Dewi, S. S. (2019). Menilik Rasa dan Sejarah di Balik Makanan Khas Bontang Gami Bawis. Akurasi.Id. Diakses pada 20 November 2020, dari https://www.akurasi.id/menilik-rasa-dan-sejarah-di-balikmakanan-khas-bontang-gami-bawis/

Fernandes, T., \& Cruz, M. (2016). Dimensions and outcomes of experience quality in tourism: The case of Port wine cellars. Journal of Retailing and Consumer Services, 31(November), 371-379. https://doi.org/10.1016/j.jretconser.2016.05.002

Gaffar, V. (2007). Customer Relationship Manajemen and Marketing Public Relation. Bandung: Alfabeta.

Ghozali, P. H. I., \& M.Com, Ph.D, CA, A. (2018). Aplikasi Analisis Multivariate dengan program IBM SPSS25 (9th ed). Semarang: BP UNDIP.

Schmitt, B. (1991). Experiential Marketing: How to get customers to sense,feel, think, act,relate to your company and brands. The Free Press, New York.

Han, H., Lee, K.-S., Song, H., Lee, S., \& Chua, B.-L. (2019). Role of coffeehouse brand experiences (sensory/affective/intellectual/behavioral) in forming patrons' repurchase intention. Journal of Hospitality and Tourism Insights, 3(1), 17-35. https://doi.org/10.1108/jhti-03-2019-0044

Huang, H., Lunhua Mao, L., Wang, J., \& Zhang, J. J. (2015). Assessing the relationships between image congruence, tourist satisfaction and intention to revisit in marathon tourism: the Shanghai International Marathon. International Journal of Sports Marketing and Sponsorship, 16(4), 4666. https://doi.org/10.1108/IJSMS-16-04-2015-B005

Ihtiyar, A., Ihtiyar, H. G., \& Galay, Y. (2018). Exploration of the antecedents and consequences of customers' service experiences. Journal of Hospitality and Tourism Insights, 1(4), 367-386. https://doi.org/10.1108/jhti-03-2018-0018

Irawan, H. (2008). Membedah strategi Kepuasan pelanggan. Jakarta: PT Gramedia.

Jeon, H. (2013). The Effect of Experiential Marketing on Customer Satisfaction and Revisit Intention of Beauty Salon Franchise Stores. Fashion Business, 17(3), 109-121. https://doi.org/10.12940/jfb.2013.17.3.109

Juniman, P. T. (2017). Gaya Hidup Masyarakat Menjadikan Bisnis Kuliner Menjanjikan. CNN Indonesia. https://www.cnnindonesia.com/gaya-hidup/20170118121405-262-187137/gayahidup-masyarakat-menjadikan-bisnis-kuliner-menjanjikan

Kotler, P., \& Keller, K. L. (2008). Marketing Management. In Marketing Management. Edisi Ketiga Belas. Jakarta: Penerbit Erlangga.

Lekstutyte, A. (2016). Experiential Marketing Practices Leading To Consumer Loyalty in Restaurant Business. Mrketing Journal, 1(September), 1-70.

Liu, P., \& Tse, E. C. Y. (2018). Exploring factors on customers' restaurant choice: an analysis of restaurant attributes. British Food Journal, 120(10), 2289-2303. https://doi.org/10.1108/BFJ-102017-0561

Manthiou, A., Kang, J., Chiang, L., \& Tang, L. (Rebecca). (2016). Investigating the Effects of Memorable Experiences: an Extended Model of Script Theory. Journal of Travel and Tourism Marketing, 33(3), 362-379. https://doi.org/10.1080/10548408.2015.1064055

Musa, G., Mohammad, I., Thirumoorthi, T., Moghavvemi, S., \& Kasim, A. (2015). Exploring visitors' 
experience using strategic experiential modules (SEMs): the case of Zoo Negara, Kuala Lumpur. International Journal of Tourism Cities, 1(3), 234-253. https://doi.org/10.1108/IJTC-08-20140012

Nararya, A. (2019). Gurihnya Industri Kuliner Bikin Ekonomi Nasional Menggeliat. Economy.Okezone.Com. https://economy.okezone.com/read/2019/01/06/320/2000558/gurihnya-industri-kuliner-bikinekonomi-nasional-menggeliat?page $=1$

Nurcahyo, B. (2016). The Role of Customer Satisfaction in a Relation of Experiential Marketing and Customer Loyalty. Advances in Social Sciences Research Journal, 3(1). https://doi.org/10.14738/assrj.31.1774

Richardson, S., Lefrid, M., Florida, C., \& Florida, C. (2019). Effect of dining experience on future intention in quick service restaurants. British Food Journal, Vol.121 No.11, pp.2620-2636. https://doi.org/10.1108/BFJ-09-2018-0617

Schiffman, L. G., \& Wisenblit, J. L. (2015). Consumer Behavior, Eleventh Edition. Edinburgh Gate England: Perason Education. (Issue 6). This Book is Available from the British Library.

Stylos, N., Vassiliadis, C. A., Bellou, V., \& Andronikidis, A. (2016). Destination images, holistic images and personal normative beliefs: Predictors of intention to revisit a destination. Tourism Management, 53, 40-60. https://doi.org/10.1016/j.tourman.2015.09.006

Terblanche, N. S. (2018). Revisiting the supermarket in-store customer shopping experience. Journal of Retailing and Consumer Services, 40(January 2018), 48-59. https://doi.org/10.1016/j.jretconser.2017.09.004

Wang, C.-H., Liu, W.-L., Cheng, C.-J., \& Huang, K.-P. (2016). The Model of Dynamic Capability in Supply Chain. International Journal of Organizational Innovation, 9(1), 35-53.

Yeh, T. M., Chen, S. H., \& Chen, T. F. (2019). The relationships among experiential marketing, service innovation, and customer satisfaction-A case study of tourism factories in Taiwan. Sustainability (Switzerland), 11(4), 1-12. https://doi.org/10.3390/su11041041 